\title{
Chapter 1 \\ Some Context: From First to Fourth Generation Universities
}

\begin{abstract}
The evolution and governance of the modern university, the balance between the needs of the consumer (students and employers) and the community (knowledge stock and needs of society).
\end{abstract}

Keywords Societal needs • University governance $\cdot$ Third generation university

It might be helpful to start by thinking about the role of a university, how it fits into the educational spectrum, how universities evolved and how they work today. In essence, universities take over when school education finishes, and offer people the opportunity to gain a higher academic degree and to perform research.

There is considerable debate about when universities started to exist. What we now know as a university can be traced back to the eleventh twelfth and thirteenth centuries where establishments in Bologna, Paris and Oxford appear to have been the earliest examples (https://www.historyofinformation.com/detail.php?id=4153). Although they were able to award a degree, they were very different organisations from what we now know as a university - they did not own buildings for example. Even earlier, there are examples of institutions where scholars could come together to study - the University of Nalanda started in fifth century India and contained buildings and a library (https://nalandauniversity.wordpress.com/about/) and the University of al-Qarawiyyin in Fez, Morocco was founded in the ninth century and has been going ever since (https://en.m.wikipedia.org/wiki/University_of_al-Qarawi yyin). Many of these had religious underpinnings.

The early universities seemed to focus on education, and have been termed first generation universities. Along with the enlightenment the next, second, generation iteration added research to education. Those were the simple days.

The third generation universities (Wissema 2009), discovered that there were ways of adding value to teaching and research - they could have a role in building national capacities, be involved in policy generation, and they could partner with actors outside the university sector. Enter the commercialisation of education and research, the involvement of entrepreneurs, and the creation of the professional university administrator to cope with increasing student numbers. As you will see in the next chapter, it is the managerial consequences of these developments that created many of the problems which we continue to experience. 
It might be useful at the start of this book to summarise the place of universities in the education system, and how universities function, although I suspect that most readers will be familiar with this. Terminology varies, and we should understand that there are many types of post-school education, usually defined as 'higher education'. The university sector is only a part of this. Education for trades maybe offered through apprenticeships to a skilled tradesman, or courses run by different bodies, and there are various ways of gaining certification of such training. This is often called vocational education and training. In Australia, for example, there is a system of Technical and Further Education (TAFE) which provides qualification awards. There is usually a national qualifications framework which defines various levels of post-school education, and national bodies that accredit organisations to provide education at these levels.

Professional bodies offer education and training towards professional accreditation, so that lawyers, accountants, architects, veterinarians, medical specialists etc. can be accredited and work in their various professions at an appropriate and accredited level. Universities may collaborate with and provide some of this professional education.

Thinking back to my own education after leaving school, it has been a mixture of apprenticeship, university education and professional accreditation.

Universities provide undergraduate education, and then graduates have the opportunity to enrol in postgraduate education. Awards at the undergraduate level are called bachelor's degrees, and postgraduate awards may be certificate, diploma, master's or doctoral degrees. The ability to award a degree is key to the importance of the university sector. Accreditation is granted to individual universities by national regulatory authorities, according to agreed criteria, which also apply to a review and renewal process.

The possession of a university degree is key to advancement to the next stage on the academic ladder for those who want a higher degree, and to professional advancement for many people. Beyond the role of a university degree in the career development of individuals, we should also ask about the overall purpose of universities for society. Is it to increase the stock of knowledge and disseminate it to improve society, or to give people the skills for the jobs they will have in the future? Put simply-are the drivers of the university sector consumer or community? Once the consumer, student or employer, is the driver, we run into the need to market and to compete. Forstenzer (2017) puts it nicely "Allowing universities to be defined primarily by their capacity to meet market criteria (such as balancing the books and delivering customer satisfaction) is a radical departure from the idea that universities exist to serve the public."

In the diagram, I have shown the balance between consumer and community in driving university priorities. Failure to achieve an appropriate balance between these has led to many of the problems I am going to describe in later chapters (Fig. 1.1).

The consumer driven approach leads to competition between providers, and requires a business-type model, which then defines the way that universities are managed and governed. In most countries, the governance of universities is overseen by a university council or board. Council members may come from local or national 

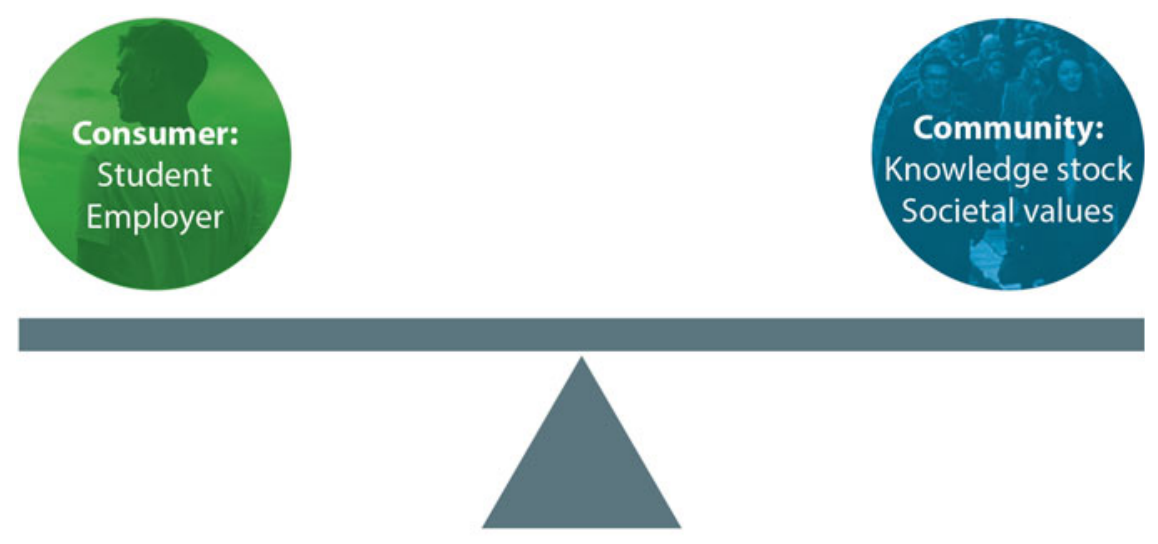

Competing drivers of the university sector

Fig. 1.1 Competing drivers of the university sector

organisations, including industry and academia, and will be chosen according to the skill set they can provide. The council's main job is to set overall strategy and appoint the chief executive officer (vice-chancellor or president) who will then be key to appointing the other senior executives such as deputy and pro vice-chancellors. If the Council, and the vice-chancellor appointed by the Council, have a business focus, that will set the scene for the way the university is run.

The governance structure within each university varies somewhat between different universities and also globally, and covers academic and business governance. Usual structures have the university divided into faculties which have a common set of interests—such as health, or humanities, or science-which are themselves split into more focused schools and then departments. Each has their own administrative structure including academics, such as deans and administrative support staff. Educational governance comes through university-wide committees, and committees in each of the faculties, schools and departments. There are also university-wide administrative structures to support finances, human resources, educational design and research infrastructure. This all usually involves a top down centralised oversight 'command and control' structure, with limited autonomy for faculties and schools and even less for departments and individual academics. Where historically the university was run by academics, it is the administrators who now have the leading management role.

Most universities offer a similar suite of courses, and span teaching and research, although there are a few specialised universities. Academic members of staff are expected to split their time between teaching, research and 'service', although the proportional split varies and there are a few teaching only and research only appointments. As we will see later, criteria for appointments and promotions depend on performance in these various roles. 
Beyond the notions of individual university governance, and national accrediting bodies who attempt to ensure quality, there are broader issues to consider. All countries provide funding for the university sector, and direct their funding in a way that attempts to meet national needs. The extent of this government support (and control) varies, as does the mix between public and private universities and the reliance on student fees. Going back to the notion of consumer or community, the greater the proportionate government input into funding, the greater can be the attempt to meet government perceptions of national and community needs-according to its political priorities. But how do other broader societal values such as fairness and equity, in particular global inequalities in access to education, and environmental sustainability find their way into university governance?

This scene setting has identified many of these themes that are picked up later in the book, which I hope will help us prepare for the next, fourth, generation of universities.

\section{References}

Forstenzer J. We are losing sight of higher education's true purpose. The Conversation; 2017. https:// theconversation.com/we-are-losing-sight-of-higher-educations-true-purpose-73637.

Nalanda University. https://nalandauniversity.wordpress.com/about/.

Norman J. The Universitas Guild: Early Origin of What We Characterize as a University. History of Information.com. https://www.historyofinformation.com/detail.php?id=4153.

University of al-Qarawiyyin. https://en.m.wikipedia.org/wiki/University_of_al-Qarawiyyin.

Wissema JG. Towards the Third Generation University: managing the University in transition. Edward Elgar Pub; 2009.

Open Access This chapter is licensed under the terms of the Creative Commons Attribution 4.0 International License (http://creativecommons.org/licenses/by/4.0/), which permits use, sharing, adaptation, distribution and reproduction in any medium or format, as long as you give appropriate credit to the original author(s) and the source, provide a link to the Creative Commons license and indicate if changes were made.

The images or other third party material in this chapter are included in the chapter's Creative Commons license, unless indicated otherwise in a credit line to the material. If material is not included in the chapter's Creative Commons license and your intended use is not permitted by statutory regulation or exceeds the permitted use, you will need to obtain permission directly from the copyright holder.

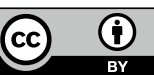

